\title{
Effect of Fat Sources in Pellet Form on Performance and Some Immune Responses of Broiler Chicks
}

\author{
M. Shahryari, A. Emadinia*, A. Davoodi, M. Omrani, M. Jafari, R. \\ Bahadoran
}

Research and Development Center, Davoodi Commercial Group, Isfahan, Iran

*Corresponding author E-mail: aemadinia@yahoo.com; Tel.: (+98) 9133051543; Fax: (+98) 31132306597

Journal of Livestock Science (ISSN online 2277-6214) 10: 59-65

Received on 20/5/2019; Accepted on 22/7/2019

doi. 10.33259/JLivestSci.2019.59-65

\begin{abstract}
The experiment was conducted to investigate the effects of different fat sources on growth performance of broiler chicks. Broiler chicks were raised from 0 to 50 days of age. Two hundred and forty broilers (Ross 308 ) were randomly assigned to one of four experimental diets. These were four replicates for each of the following diets: A) Soybean oil, B) Free fatty acids, C) Grease oil, and D) Poultry oil. The results showed that the highest body weight and daily weight gain in 8-15 d, 16-25 d, 26-39 d, 40-44 d, and 45-50 were obtained in broilers fed on soybean oil diets $(\mathrm{P}<0.05)$. In 0-50 day oil the feed intake and daily weight gain of broilers fed on soybean oil was higher than other fat sources $(\mathrm{P}<0.05)$. According to findings of recent study, the growth performance of broiler fed on poultry oil and grease oil was poor compare to other fat sources. The growth performance of broilers fed on free fatty acids diet was slightly better than grease oil and poultry oil sources. The soybean meal oil and poultry fat oil supplementation significantly increased and decreased carcass weight percentage, respectively $(\mathrm{P}<0.05)$. Antibody titer against Newcastle diseases and Influenza viruses were not affected by different fat sources $(\mathrm{P}>0.05)$.
\end{abstract}

Keywords: Broiler; Fat; Performance; Immunity 


\section{Introduction}

The inclusion of fat and oil is a common practice in poultry production to increase the energy content of diet. Adding dietary fat decreased passage rate of the digesta from the gastrointestinal tract, so the nutrient absorption and utilization will be better (Peebles et al., 2000; Baiao and Lara, 2005; Latshaw, 2008). It was suggested that fat metabolism and deposition in poultry can be affected by different dietary fat (Snaz et al., 2000; Pesti et al., 2002). The inclusion of fat to poultry diet, in addition to providing energy, ameliorates the absorption of fat-soluble vitamins, reduces the pulverulence, and enhances the palatability of the rations.

The amount of fat consumption decreased and feed efficiency was improved, when fat sources increased in poultry diets (Jeffri et al., 2010). Nowadays, a number of different fat sources from animal and vegetable sources are used in poultry diets (Sanz et al., 2000). Soybean oil is one of the main sources of vegetable fat which is used in poultry diets due to the suitable fatty acid composition and high amount of metabolizable energy (Burlikowska et al., 2010).

It was reported that broilers fed $8 \%$ beef tallow in the diet a significant reduction of feed efficiency compared to birds fed sunflower or fish oil was observed (Newman et al., 2002). While, adding 3\% of canola oil in broiler diet caused in a significant improvement in body weight and feed conversion ratio in comparison to birds fed animal fat (Newman et al., 2002). . The present experiment was undertaken to determine the effects of different dietary fat sources on broiler performance, carcass characteristics and antibody titer against Newcastle Diseases and Avian Influenza viruses.

\section{Materials and methods}

The experiment was conducted according to the Animal Care Committee of the Animal Science Department, Islamic Azad University, Isfahan (Khorasgan) Branch, Isfahan, Iran. The one day old broilers were purchased from a commercial hatchery, individually weighed and 240 broilers randomly allocated to the pens with dimensions of $1.20 \times 1 \times 1 \mathrm{~m}$, length, width, height. The study was conducted in a completely randomized design with 4 treatments; each treatment was replicated 5 times, with each replicate comprising one pen of 12 birds.

The broilers were vaccinated following the standard vaccination schedule, in order to decrease the stress induced by vaccination to broilers, a multi-electrolyte solution was added in drinking water, $24 \mathrm{~h}$ before and after vaccination.

Pens were equipped with a hanging feeder, nipple drinker and wood shavings. Broilers from 0-7 d of age fed on with commercial diet and then a four phase feeding program included of 8-15 d, 16-25 d, 26-39 d, 40-44 d, 45-50 d. Birds were fed 4 diets containing different fat sources (soybean oil, fatty acid, grease oil and poultry oil) formulated to meet or exceed broiler nutrient requirements (Ross 308) recommendation. All the fat sources were purchased from Teyhoo Sanaat Parsian Co. The mentioned company produce raw soybean oil, mixture of soybean oil and poultry oil fatty acid, refined fast food and restaurant oil, and poultry oil from slaughter house by-product. The reason of fat sources selection was, they are conventional fat sources in poultry production in Iran and they have a noticeable price difference in some situation. The dietary treatments consisted of $1,1.3,1.3$ and $1.6 \%$ in starter, grower, finisher one and two, respectively.

Ingredients and chemical composition of the basal diets are shown in Table 1. Feed (pellet form) and water were provided ad libitum throughout the whole trial. Body weight (BW), feed intake (FI), daily weight gain (DWG) and feed conversion ratio (FCR) of broilers were obtained at the end of each period.

All broilers were intramuscularly immunized with a killed vaccine of Newcastle and Avian Influenza (H9N2) viruses at age of 7 days. On day 33 blood sample was collected from the wing vein of two birds per each replicate and serum antibody titers against Newcastle and Influenza viruses in serum were determined by haemaglutination inhibition (HI) test and were expressed as the logarithm base 2 (Jahanian, 2009).

At 50 days of age two birds were selected randomly from each replicate, slaughtered and the carcass, heart, liver, abdominal fat, spleen, bursa of fabricius, proventriculus, gizzard, pancreas, deudenum, jejunum, ileum and cecum were collected, weighed and expressed as a percentage of live body weight.

\section{Statistical analysis}

Data were analyzed using the ANOVA general linear model of SAS software as a completely randomized design. Means were compared by the LSD method. Significant implies $\mathrm{P}<0.05$ unless stated otherwise. 
Table 1. Ingredient and composition of the diet

\begin{tabular}{|c|c|c|c|c|}
\hline Diet composition & $\begin{array}{l}\text { Starter } \\
(7-14 d)\end{array}$ & $\begin{array}{l}\text { Grower } \\
\text { (14-28d) }\end{array}$ & $\begin{array}{l}\text { Finisher } 1 \\
(28-42 d)\end{array}$ & $\begin{array}{l}\text { Finisher } 2 \\
(42-50 \mathrm{~d})\end{array}$ \\
\hline Corn & 45.7 & 55.5 & 57.7 & 58.9 \\
\hline Soybean meal & 25.5 & 20 & 14 & 13 \\
\hline Soybean Oil & 1 & 1.3 & 1.6 & \\
\hline Salt & 0.2 & 0.2 & 0.2 & 0.2 \\
\hline MCP & 1 & 0.97 & 0.71 & 0.68 \\
\hline $\mathrm{CaCo}_{3}$ & 1.75 & 1.7 & 1.55 & 1.5 \\
\hline Lysine & 0.35 & 0.35 & 0.35 & 0.31 \\
\hline Methionine & 0.24 & 0.23 & 0.2 & 0.19 \\
\hline Threonine & 0.11 & 0.12 & 0.14 & 0.11 \\
\hline $\mathrm{NaHCo}_{3}$ & 0.13 & 0.13 & 0.13 & 0.15 \\
\hline Mineral premix $^{1}$ & 0.14 & 0.12 & 0.09 & 0.09 \\
\hline Vitamin premix ${ }^{2}$ & 0.14 & 0.12 & 0.09 & 0.09 \\
\hline Rovabio Enzyme & 0.005 & 0.005 & 0.005 & 0.005 \\
\hline Choline chloride & 0.05 & 0.05 & 0.035 & 0.035 \\
\hline Wheat DDGS & 3 & 4 & 7 & 7 \\
\hline Rapeseed meal & 6 & 6 & 8 & 8 \\
\hline Phytase & 0.01 & 0.01 & 0.01 & 0.01 \\
\hline $\begin{array}{ll}\begin{array}{l}\text { Dehulled } \\
\text { meal }\end{array} & \text { Sesame } \\
\end{array}$ & 2 & 2 & 2 & 2 \\
\hline Toxin binder & 0.2 & 0.2 & 0.2 & 0.2 \\
\hline Corn gluten meal & 2.5 & 2 & 1 & 1 \\
\hline Wheat & 10 & 5 & 5 & 5 \\
\hline \multicolumn{5}{|l|}{$\begin{array}{l}\text { Calculated } \\
\text { composition }\end{array}$} \\
\hline $\begin{array}{l}\text { Metabolizable } \\
\text { energy (Kcal/Kg) }\end{array}$ & 2890 & 2970 & 3020 & 3030 \\
\hline Crude protein $\%$ & 21.4 & 19.3 & 18 & 17.5 \\
\hline Digestible lysine\% & 1.15 & 1.04 & 0.92 & 0.87 \\
\hline $\begin{array}{l}\text { Digestible } \\
\text { Met+Cys\% }\end{array}$ & 0.9 & 0.83 & 0.78 & 0.76 \\
\hline Digestible Thr\% & 0.79 & 0.72 & 0.68 & 0.64 \\
\hline Calcium\% & 0.98 & 0.94 & 0.84 & 0.81 \\
\hline $\begin{array}{l}\text { Available } \\
\text { phosphorous\% }\end{array}$ & 0.47 & 0.46 & 0.4 & 0.39 \\
\hline $\mathrm{Na}$ & 0.17 & 0.16 & 0.17 & 0.17 \\
\hline $\mathrm{Cl}$ & 0.2 & 0.2 & 0.2 & 0.2 \\
\hline
\end{tabular}

${ }^{1}$ Vitamin premix provided per kg of diet: Vitamin A: $9000 \mathrm{IU}$, Vitamin D3 $4000 \mathrm{IU}$, Vitamin E $63 \mathrm{mg}$, Vitamin K 2.3 mg, Vitamin B1 mg 2.6, Vitamin B2 6.5mg, Vitamin B3 48, Vitamin B5 15, Vitamin B6 3, Vitamin H2 0.16, Vitamin B9 1.7, Vitamin B12 0.013 ; ${ }^{2}$ Mineral premix provided per kg of diet: Zn 126, Mn 105 mg, Fe 38 mg, Cu 16 mg, I $1.3 \mathrm{mg}$, Se $0.38 \mathrm{mg}$.

\section{Results}

\section{Performance}

The effect of different fat sources on performance parameters of broilers are illustrated in Table 2. There were no significant differences between fat sources on FI of broilers in 8-15 $\mathrm{d}(\mathrm{P}>0.05)$. In 16-25 d the broilers fed on diets containing free fatty acid and poultry oil had highest and lowest FI $(\mathrm{P}<0.05)$, respectively. The FI of broilers fed on diet containing grease oil in 26-39 d and 40-44d was significantly lower than other fat sources $(\mathrm{P}<0.05)$. In whole rearing period (8-50 d) using soybean oil and grease oil cause to increase and decrease FI of broilers, respectively $(\mathrm{P}<0.05)$.

The results related to BW of broilers in 8-15 d, 16-25 d, 26-39 d and 39-42 d was similar, using soybean oil and poultry oil significantly increased and decreased broilers BW, respectively $(\mathrm{P}<0.05)$. The broilers received diets supplemented with soybean oil in 8-50 d had the highest BW compare to other fat sources $(\mathrm{P}<0.05)$. 
Table 2. Effect of different fat sources on broiler performance at different phase.

\begin{tabular}{|c|c|c|c|c|c|}
\hline & Soybean oil & Free Fatty acids & Grease oil & Poultry oil & $\begin{array}{l}\mathrm{p}- \\
\text { value }\end{array}$ \\
\hline \multicolumn{6}{|l|}{$8-15 \mathrm{~d}$} \\
\hline DFI & $52.01^{\mathrm{a}} \pm 0.47$ & $51.81^{\mathrm{a}} \pm 0.05$ & $51.88^{\mathrm{a}} \pm 0.44$ & $51.76^{\mathrm{a}} \pm 0.11$ & 0.95 \\
\hline $\mathrm{BW}$ & $530.00^{\mathrm{a}} \pm 4.51$ & $528.37^{\mathrm{a}} \pm 1.60$ & $518.75^{\mathrm{ab}} \pm 4.55$ & $515.87^{\mathrm{b}} \pm 4.11$ & 0.05 \\
\hline DWG & $48.57^{\mathrm{a}} \pm 0.64$ & $48.33^{\mathrm{ab}} \pm 0.22$ & $46.96^{\mathrm{b}} \pm 0.65$ & $47.30^{\mathrm{ab}} \pm 0.04$ & 0.07 \\
\hline FCR & $1.07^{\mathrm{bc}} \pm 0.009$ & $1.08^{\mathrm{ab}} \pm 0.002$ & $1.05^{\mathrm{c}} \pm 0.004$ & $1.09^{\mathrm{a}} \pm 0.003$ & 0.002 \\
\hline \multicolumn{6}{|c|}{$16-25 \mathrm{~d}$} \\
\hline DFI & $93.36^{\mathrm{ab}} \pm 0.91$ & $96.02^{\mathrm{a}} \pm 1.69$ & $92.58^{\mathrm{b}} \pm 0.72$ & $87.56^{\mathrm{c}} \pm 0.77$ & 0.0005 \\
\hline BW & $1093.13^{\mathrm{a}} \pm 6.55$ & $1082.18^{\mathrm{a}} \pm 7.91$ & $1080.50^{\mathrm{ab}} \pm 13.02$ & $1052.13^{\mathrm{b}} \pm 10.33$ & 0.05 \\
\hline DWG & $56.31^{\mathrm{a}} \pm 0.98$ & $55.38^{\mathrm{ab}} \pm 0.86$ & $56.17^{\mathrm{a}} \pm 0.96$ & $52.68^{\mathrm{b}} \pm 1.05$ & 0.06 \\
\hline FCR & $1.70^{\mathrm{ab}} \pm 0.03$ & $1.73^{\mathrm{a}} \pm 0.01$ & $1.64^{\mathrm{b}} \pm 0.01$ & $1.69^{\mathrm{ab}} \pm 0.01$ & 0.08 \\
\hline \multicolumn{6}{|l|}{$26-39 d$} \\
\hline DFI & $130.38^{\mathrm{a}} \pm 0.43$ & $131.57^{\mathrm{a}} \pm 0.74$ & $125.74^{\mathrm{b}} \pm 0.01$ & $130.23^{\mathrm{a}} \pm 2.32$ & 0.02 \\
\hline $\mathrm{BW}$ & $2012^{\mathrm{a}} \pm 3.41$ & $1995^{\mathrm{a}} \pm 11.60$ & $1915^{\mathrm{b}} \pm 19.01$ & $1870^{\mathrm{C}} \pm 13.40$ & 0.0001 \\
\hline DWG & $76.59^{\mathrm{a}} \pm 0.72$ & $76.11^{\mathrm{a}} \pm 1.30$ & $68.51^{\mathrm{b}} \pm 1.20$ & $63.89^{\mathrm{c}} \pm 2.21$ & 0.0001 \\
\hline FCR & $1.70^{\mathrm{c}} \pm 0.01$ & $1.73^{\mathrm{c}} \pm 0.03$ & $1.83^{\mathrm{b}} \pm 0.03$ & $2.11^{\mathrm{a}} \pm 0.02$ & 0.0001 \\
\hline \multicolumn{6}{|l|}{$40-44 d$} \\
\hline DFI & $183.83^{\mathrm{ab}} \pm 0.00$ & $188.94^{\mathrm{ab}} \pm 3.95$ & $180.91^{\mathrm{b}} \pm 1.59$ & $191.99^{\mathrm{a}} \pm 3.81$ & 0.06 \\
\hline $\mathrm{BW}$ & $2604.00^{\mathrm{a}} \pm 8.61$ & $2580.75^{\mathrm{a}} \pm 23.87$ & $2418.68^{\mathrm{b}} \pm 21.85$ & $2362.78^{b} \pm 40.54$ & 0.0001 \\
\hline DWG & $98.62^{\mathrm{a}} \pm 1.39$ & $97.54^{\mathrm{ab}} \pm 2.79$ & $93.41^{\mathrm{ab}} \pm 1.63$ & $90.15^{\mathrm{b}} \pm 4.34$ & 0.16 \\
\hline FCR & $1.86^{\mathrm{c}} \pm 0.02$ & $1.88^{\mathrm{bc}} \pm 0.02$ & $1.93^{\mathrm{b}} \pm 0.02$ & $2.05^{\mathrm{a}} \pm 0.02$ & 0.0002 \\
\hline \multicolumn{6}{|c|}{$45-50 \mathrm{~d}$} \\
\hline DFI & $204.05^{\mathrm{a}} \pm 3.14$ & $192.57^{\mathrm{b}} \pm 0.06$ & $184.22^{\mathrm{c}} \pm 0.19$ & $205.42^{\mathrm{a}} \pm 1.74$ & 0.0001 \\
\hline $\mathrm{BW}$ & $3113.00^{\mathrm{a}} \pm 34.58$ & $3045.13^{b} \pm 9.50$ & $2900.00^{c} \pm 17.69$ & $2906.72^{\mathrm{c}} \pm 7.14$ & 0.0001 \\
\hline DWG & $92.84^{\mathrm{a}} \pm 1.63$ & $85.14^{\mathrm{b}} \pm 0.21$ & $80.20^{c} \pm 1.17$ & $77.45^{\mathrm{c}} \pm 1.38$ & 0.0001 \\
\hline FCR & $2.19^{\mathrm{c}} \pm 0.03$ & $2.23^{\mathrm{bc}} \pm 0.02$ & $2.29^{\mathrm{b}} \pm 0.03$ & $2.65^{\mathrm{a}} \pm 0.03$ & 0.0001 \\
\hline \multicolumn{6}{|l|}{$8-50 \mathrm{~d}$} \\
\hline DFI & $124.78^{\mathrm{a}} \pm 0.26$ & $124.68^{\mathrm{a}} \pm 1.23$ & $119.82^{b} \pm 0.31$ & $123.55^{\mathrm{a}} \pm 0.78$ & 0.01 \\
\hline DWG & $71.29^{\mathrm{a}} \pm 0.84$ & $70.59^{\mathrm{a}} \pm 0.77$ & $66.08^{b} \pm 0.43$ & $64.86^{\mathrm{b}} \pm 0.94$ & 0.0001 \\
\hline FCR & $1.76^{\mathrm{d}} \pm 0.006$ & $1.81^{\mathrm{c}} \pm 0.005$ & $1.83^{\mathrm{b}} \pm 0.003$ & $1.89^{\mathrm{a}} \pm 0.001$ & 0.0002 \\
\hline
\end{tabular}

The highest DWG in 8-15 d was obtained in broilers consumed diet with soybean oil, while the DWG of broilers consumed diet with grease oil decreased $(\mathrm{P}<0.05)$. The DWG of broilers consumed diets with poultry oil significantly decreased $(\mathrm{P}<0.05)$. In $26-39 \mathrm{~d}, 40-44 \mathrm{~d}$ and $45-50 \mathrm{~d}$ the similar trend was observed in DWG of broilers, the highest and lowest DWG was obtained by soybean oil and poultry oil supplementation $(\mathrm{P}<0.05)$.

The data related to FCR of broilers in Table 2 shows that in 8-15 $\mathrm{d}$ and 16-25 $\mathrm{d}$ the lowest FCR was obtained in broilers fed on diet containing grease oil $(\mathrm{P}<0.05)$. In $26-39 \mathrm{~d}, 40-44 \mathrm{~d}$ and 45-50 $\mathrm{d}$ the results shows that by using soybean oil the FCR of broilers significantly decreased in comparison to other fat sources $(\mathrm{P}<0.05)$.

Carcass

The percentage of carcass, abdominal fat, spleen, proventriculus, gizzard, deudenum, jejunum, ileum and cecum of broilers affected by fat sources $(\mathrm{P}<0.05)$, but no significant differences were found for heart, liver, bursa of fabricius and pancreas (Table 3 ).

The broilers fed on soybean oil and poultry oil diet had the highest and lowest carcass percentage, respectively $(\mathrm{P}<0.05)$. Also, percentage of abdominal fat was lowest and highest in soybean oil and poultry oil diet, respectively $(\mathrm{P}<0.05)$. The lowest spleen weight was observed in grease oil diet $(\mathrm{P}<0.05)$. The broilers received diets supplemented with free fatty acids had lowest proventriculus and gizzard weight $(\mathrm{P}<0.05)$, while soybean oil and grease oil increased proventriculus and gizzard weight, respectively $(\mathrm{P}<0.05)$.

Results shows that deudenum weight of broilers fed poultry oil diet had more deudeum weight than other fat sources $(\mathrm{P}<0.05)$. The free fatty acids as a fat source in broiler diets increase jejunum and ileum weight and 
soybean meal oil decreased the weight of mentioned parts $(\mathrm{P}<0.05)$. The highest and lowest cecum weight was observed in soybean oil and poultry oil diets, respectively $(\mathrm{P}<0.05)$.

Antibody titer

The antibody titer against Newcastle and Influenza vaccine were not affected by fat sources $(\mathrm{P}>0.05)$. Free Fatty acids insignificantly reduced antibody titer against Newcastle and Influenza viruses ( $>>0.05)$ (Table 4).

Table 3. Effect of different fat sources on carcass characteristics of broilers at 50 day of age (\% Live weight).

\begin{tabular}{|l|l|l|l|l|l|}
\hline Parameters & Soybean oil & Free Fatty acids & Grease oil & Poultry oil & p-value \\
\hline Carcass & $66.51^{\mathrm{a}} \pm 0.16$ & $63.82^{\mathrm{bc}} \pm 0.32$ & $64.56^{\mathrm{b}} \pm 0.26$ & $63.00^{\mathrm{c}} \pm 0.33$ & 0.0001 \\
\hline Heart & $0.48^{\mathrm{a}} \pm 0.01$ & $0.49^{\mathrm{a}} \pm 0.02$ & $0.46^{\mathrm{a}} \pm 0.02$ & $0.53^{\mathrm{a}} \pm 0.02$ & 0.23 \\
\hline Liver & $1.84^{\mathrm{a}} \pm 0.08$ & $1.92^{\mathrm{a}} \pm 0.07$ & $2.04^{\mathrm{a}} \pm 0.17$ & $2.00^{\mathrm{a}} \pm 0.09$ & 0.65 \\
\hline Abdominal fat & $1.97^{\mathrm{b}} \pm 0.02$ & $2.43^{\mathrm{a}} \pm 0.10$ & $2.31^{\mathrm{a}} \pm 0.18$ & $2.61^{ \pm} \pm 0.04$ & 0.006 \\
\hline Spleen & $0.12^{\mathrm{a}} \pm 0.00$ & $0.11^{\mathrm{a}} \pm 0.00$ & $0.08^{\mathrm{b}} \pm 0.01$ & $0.12^{\mathrm{a}} \pm 0.01$ & 0.04 \\
\hline Bursa of fabricius & $0.04^{\mathrm{a}} \pm 0.007$ & $0.03^{\mathrm{a}} \pm 0.001$ & $0.04^{\mathrm{a}} \pm 0.006$ & $0.04^{\mathrm{a}} \pm 0.008$ & 0.27 \\
\hline Proventriculus & $0.36^{\mathrm{a}} \pm 0.02$ & $0.31^{\mathrm{b}} \pm 0.00$ & $0.35^{\mathrm{a}} \pm 0.01$ & $0.34^{\mathrm{ab}} \pm 0.01$ & 0.09 \\
\hline Gizzard & $1.28^{\mathrm{bc}} \pm 0.00$ & $1.23^{\mathrm{c}} \pm 0.02$ & $1.40^{\mathrm{a}} \pm 0.03$ & $1.35^{\mathrm{ab}} \pm 0.01$ & 0.0009 \\
\hline Pancreas & $0.13^{\mathrm{a}} \pm 0.01$ & $0.16^{\mathrm{a}} \pm 0.01$ & $0.14^{\mathrm{a}} \pm 0.01$ & $0.17^{\mathrm{a}} \pm 0.01$ & 0.26 \\
\hline Deudenum & $0.52^{\mathrm{a}} \pm 0.04$ & $0.55^{\mathrm{a}} \pm 0.02$ & $0.51^{\mathrm{b}} \pm 0.02$ & $0.61^{\mathrm{a}} \pm 0.02$ & 0.15 \\
\hline Jejunum & $0.7^{\mathrm{c}} \pm 0.03$ & $1.31^{\mathrm{a}} \pm 0.00$ & $0.94^{\mathrm{b}} \pm 0.06$ & $1.29^{\mathrm{a}} \pm 0.08$ & 0.0001 \\
\hline Ileum & $0.72^{\mathrm{b}} \pm 0.07$ & $0.97^{\mathrm{a}} \pm 0.03$ & $0.88^{\mathrm{ab}} \pm 0.03$ & $0.96^{\mathrm{a}} \pm 0.09$ & 0.04 \\
\hline Cecum & $1.02^{\mathrm{a}} \pm 0.02$ & $1.02^{\mathrm{a}} \pm 0.18$ & $0.59^{\mathrm{b}} \pm 0.06$ & $0.52^{\mathrm{b}} \pm 0.06$ & 0.003 \\
\hline
\end{tabular}

${ }^{\mathrm{a}-\mathrm{c}}$ Means within the row with no common superscripts differ significantly.

Table 4. Effect of different fat sources on antibody titer against Newcastle diseases and Influenza viruses of broilers.

\begin{tabular}{|l|l|l|l|l|l|}
\hline Antibody titer & Soybean oil & Free Fatty acids & Grease oil & Poultry oil & p-value \\
\hline $\begin{array}{l}\text { AI } \\
(\text { Log2 HI titer })\end{array}$ & $5.11^{\mathrm{a}} \pm 0.20$ & $4.55^{\mathrm{a}} \pm 0.17$ & $4.88^{\mathrm{a}} \pm 0.20$ & $4.88^{\mathrm{a}} \pm 0.26$ & 0.33 \\
\hline $\begin{array}{l}\text { ND } \\
(\text { Log2 HI titer })\end{array}$ & $3.88^{\mathrm{a}} \pm 0.20$ & $3.44^{\mathrm{a}} \pm 0.17$ & $3.66^{\mathrm{a}} \pm 0.23$ & $3.77^{\mathrm{a}} \pm 0.22$ & 0.49 \\
\hline
\end{tabular}

${ }^{\mathrm{a}-\mathrm{c}}$ Means within the row with no common superscripts differ significantly. ND: Newcastle diseases, AI: Avian Influenza.

\section{Discussion}

\section{Performance}

In agreement with obtained results, Balevi and Coskun (2000) observed that body weight of broilers fed corn oil diet was higher than those fed soybean oil diet or beef tallow diet. As observed in present study, the body weight of broilers in 8-15 d, 16-25 d and 40-44 $\mathrm{d}$ fed poultry oil diet was lower $(\mathrm{P}<0.05)$ than other broilers fed diet with different fat sources. Studies show that broilers fed vegetable oil diets obtain more weight than those fed animal fat diets (Chung et al., 1993). Salehifar et al (2017) observed that broilers fed on diets supplemented with myrtle essential oil and virginiamycin compare to control diet, significantly gained high body weight gain in all weeks, except during 0-14 days of age $(\mathrm{P}<0.05)$. The reason for the better body weight and DWG of the broilers fed soybean oil diet was the lower digestibility of the saturated fatty acids in comparison to unsaturated fatty acids (Zollitsch et al., 1997). Azman et al (2004) shown that weight gain was lower in broilers fed on the diets supplemented with poultry grease compare to soybean oil or beef tallow for 5 to 21 days of age. In contrast to obtained results, Azman et al (2004) indicated that poultry grease diets caused improvement in the feed conversion ratio of broilers.

In present experiment the broilers fed on soybean oil diet in 40-44 $\mathrm{d}, 45-50 \mathrm{~d}$ and 8-50 $\mathrm{d}$ had lowest FCR than other fat sources $(\mathrm{P}<0.05)$. The findings of Tabeidian et al $(2005)$ are according to obtained results, they reported that broilers feeding a diet contain $2.5 \%$ soybean oil and protein level $10 \%$ more than NRC recommendation resulted to lowest feed conversion ratio. The better body weight and daily weight gain of broilers fed soybean oil diet could be explained by the positive effect of this fat source on the reduced passage rate of the digesta through the gastrointestinal tract, so the nutrient absorption and utilization will be better (Latshaw, 2008). The higher body weight, daily weight gain and better feed conversion ratio was observed in broilers fed soybean oil 
diet can be due to improved nutrient digestibility and better nutrient absorption as reflected by improved feed efficiency. Danicke et al $(1997,2000)$ showed that live weight gain and feed conversion ratio were better in birds fed soybean oil diets $(100 \mathrm{~g} / \mathrm{kg})$ compare to those broilers that were fed diet containing tallow as the energy source. Also, Zollitsch et al (1997) suggested that broilers were fed diets containing soybean oil diet performed better than broilers fed animal-vegetable fat blended diets. Unlike the obtained results in present study, Pesti et al (2002) did not observe significant differences in 39 day body weight or 18-39 body weight gain because of fat source. Also, they did not observe differences in gains or FCR due to fat source. Tabeidian et al (2005) reported that inclusion of soybean oil in broilers diet had no significant effect on feed intake in 7-21 days, but increasing soybean oil (5\%) increased feed intake. Ali et al (2001) observed that total feed consumption of the broilers fed $10 \%$ soybean oil diet was significantly lower than the broilers fed lower level of soybean oil diets. Similar to recent study, Nitsan et al (1997) showed that adding 3\% soybean oil than 0\% in the diet improved weight gain of broilers.

Carcass characteristics

In contrast with obtained findings in recent study, Tabeidian et al (2005) found that feeding different levels of soybean oil and protein had no effect on carcass, intestine and proventriculus weight, but similar to recent findings pancrease weight was not affected by fat sources and protein levels. Similarly, Tabeidian et al (2005) reported that lowest abdominal fat was observed in broilers fed a diet containing $7.5 \%$ soybean oil $(\mathrm{P}<0.05)$. Some reports show that unsaturated dietary fat may be used for metabolic purposes, so this could affect deposition of body fat (Awad, 1981).

Sharifi et al (2012) observed that broilers fed soybean oil or free fatty acid supplemented diets had enlarged livers than those fat unsupplemented diets. Evidence show that dietary fat sources mainly influence abdominal fat deposition in broilers. For example, dietary fats rich in saturated fatty acids significantly increased the weights of abdominal fat in broilers (Velasco et al., 2010; Ferrini et al., 2008) which is support the results of recent experiment. Our findings are in consistent with Poorghasemi et al (2013) who observed similar performance, carcass yield and cut yields of broilers fed diets supplemented with poultry fat, canola, sunflower, corn, soybean or lard. In part agreement with our study, Poorghasemi et al (2013) observed that by using different fat sources abdominal fat pad production tended to be lower in broilers fed $4 \%$ of sunflower oil, but carcass yield and most of organ relative weights were not affected. Shahryar et al (2011) reported that the addition $6 \%$ abdominal fat caused a significant increase of abdominal fat weight compared to unsupplemneted diets.

Antibody Titer

The research related to the effect of fat sources on Newcastle Diseases and Avian Influenza Viruses are scant. In findings of Allahyari-Bake and Jahanian (2017) dietary palm fat powder supplementation increased infectious bursal disease and sheep red blood cell antibody titers. The obtained results in recent study showed that free fatty acid supplementation insignificantly decreased antibody titer production; this reduction might because of fat soluble vitamin deficiency in free fatty acid source.

Conclusion

As observed, carcass percentage was increased by soybean oil $(\mathrm{P}<0.05)$. The higher and lower abdominal fat was obtained by poultry oil and soybean oil supplementation $(\mathrm{P}<0.05)$. Antibody titer against Avian Influenza and Newcastle Diseases viruses were not affected by different fat sources in broiler diets $(\mathrm{P}>0.05)$. As a conclusion broilers fed soybean oil and free fatty acids diet, respectively had better growth performance than broilers received other fat sources.

Acknowledgment

This project was supported by the Davoodi Commercial Group.

Conflict of Interests

The authors declare that there is no conflict of interests regarding the publication of this paper.

\section{References}

1) Allahyari-Bake $S$, Jahanian, R, 2017. Effects of dietary fat source and supplemental lysophosphatidylcholine on performance, immune responses, and ileal nutrient digestibility in broilers fed corn/soybean meal or corn/wheat/soybean meal based diets. Poultry Science 96: 1149-1158.

2) Ali ML, Miah AG, Salma U, Chowdhury RP, 2001. Effect of soybean oil on finisher period of broiler at hot weather in Bangladesh. On Line Journal of Biological Science 8: 714-716.

3) Awad AB, 1981. Effect of dietary lipids on composition and glucose utilization by rat adipose tissue. Journal of Nutrition 111: 34-39.

4) Azman MA, Konar V, Seven PT, 2004. Effects of different fat sources on performance and carcass fatty acid composition of broiler chickens. Revue de Medecine Veterinaire 156: 278-286. 
5) Balevi T, Coskun B. 2000. Effects of some oils used in broiler rations on performance and fatty acid compositions in abdominal fat. Revue de Medecine Veterinaire 151: 937-944.

6) Baiao NC, Lara LJC, 2005. Oil and fat in broiler nutrition. Brazilian Journal Poultry Science 1: 129-141.

7) Burlikowska K, Piotrowska A, Szymeczko R, 2010. Effect of dietary fat type on performance, biochemical indices and fatty acids profile in the blood serum of broiler chickens. Journal of Animal Feed Science 19: 440-451.

8) Chung HC, Guenter W, Rotter RG, Crow GH, Stanger NE, 1993. Effects of dietary fat source on sudden death syndrome and cardiac sarcoplasmic reticular calcium transport in broiler chickens. Poultry Science 72: 310316.

9) Danicke S, Jeroch H, Bottcher W, Simon O, 2000. Interactions between dietary fat type and enzyme supplementation in broiler diets with high pentosan contents: effects on precaecal and total tract digestibility of gross energy, digesta viscosity and weights of small intestine. Animal Feed Science and Technology 84: 879-294.

10) Danicke S, Simon O, Jeroch H, Bedford M, 1997. Interactions between dietary fat type and xylanase supplementation when rye-based diets are fed to broiler chickens 2. Performance, nutrient digestibility and the fat-soluble vitamin status of livers. British Poultry Science 38: 546-556.

11) Ferrini G, Baucells MD, Esteve-Garcia E, Barroeta AC, 2008. Dietary polyunsaturated fat reduces skin fat as well as abdominal fat in broiler chickens. Poultry Science 87: 528-535.

12) Jahanian $R$, Nassiri Moghaddam $H$, Rezaei A, 2008. Improved broiler chick performance by dietary supplementation of organic zinc sources. Asian-Australian Journal of Animal Science 21: 1348-1354.

13) Jeffri D, Firman H, Kamyab A, 2010. Comparison of soybean oil with an animal/vegetable blend at four energy levels in broiler rations from hatch to market. International Journal of Poultry Science 9: 1027-1030.

14) Latshaw JD, 2008. Daily energy intake of broiler chickens altered by proximate nutrient content and from of the diet. Poultry Science 87: 89-95.

15) Newman RE, Bryden WL, Fleck E, Ashes JR, Buttermer WA, Storlien LH, Dowing JA, 2002. Dietary n-3 and n-6 fatty acids alter avian metabolism: molecular-species composition of breast-muscle phospholipids. British Journal of Nutrition 88: 19-28.

16) Nitsan Z, Dvorin A, Zoref Z, Mokady S, 1997. Effect of added soybean oil and dietary energy on metabolizable and net energy of broiler diets. British Poultry Science 38: 101-106.

17) Peebles ED, Zumwalt CD, Doyle SM, Gerard PD, Latour MA, Boyle CR, Smith TW, 2000. Effect of breeder age and dietary fat source and level on broiler hatching egg characteristics. Poultry Science 79: 698-704.

18) Pesti GN, Bakalli RI, Qiao M, \& Sterling KG, 2002. A comparison of eight grades of fats as broiler feed ingredients. Poultry Science 81: 382-390.

19) Poorghasemi M, Seidavi A, Alaw-Qotbi AA, Laudadio V, Tufareli V, 2013. Influence of dietary fat source on growth performance responses and carcass traits of broiler chicks. Asian-Australasian Journal of Animal Science 26(5): 705-710.

20) Salehifar E, Abbasi M, Bahari-Kashani, 2017. Effects of Myrtle (Myrtus communis) essential oil on growth performance, carcass characteristics, intestinal morphology, immune response and blood parameters in broiler chickens. Journal of Livestock Science 8: 63-71.

21) Sanz M, Flores A, Lopez-Bote CJ, 2000. The metabolic use of energy from dietary fat in broilers is affected by fatty acid saturation. British Poultry Science 41: 61-68.

22) Shahryar HA, Salamatdoustnobar R, Lak A, Lotfi AA, 2011. Effect of dietary supplemented canola oil and poultry fat on the performance and carcass characteristics of broiler chickens. Current Research Journal of Biological Science 3: 388-392.

23) Sharifi SD, Dibamehr A, Lotfollahian H, Baurhoo B, 2012. Effects of flavomycin and probiotic supplementation diets containing different sources of fat on growth performance, intestinal morphology, apparent metabolizable energy, and fat digestibility in broiler chickens. Poultry Science 91: 918-927.

24) Tabeidian A, Sadeghi GH, Pourreza J, 2005. Effect of dietary protein levels and soybean oil supplementation on broiler performance. International Journal of Poultry Science 4(10), 799-803.

25) Velasco S, Ortiz LT, Alzueta C, Rebole A, Trevino J, Rodriguez L, 2010. Effect of inulin supplementation and dietary fat sources on performance, blood serum metabolites, liver lipids, abdominal fat deposition, and tissue fatty acid composition in broiler chickens. Poultry Science 89: 1651-1662.

26) Zollitsch W, Knaus W, Alichinger F, Lettner F. 1997. Effects of different dietary fat sources on performance and carcass characteristics of broilers. Animal Feed Science and Technology 66: 63-73. 